\title{
THE ROLE OF MACRONUTRIENTS IN THE IMPLEMENTATION OF THE CORRECTIVE EFFECT OF LOW-MINERALIZED WATER IN EXPERIMENTAL METABOLIC SYNDROME
}

\author{
Anatoliy Gozhenko', Nataliia Badiukl, Boris Nasibullin², Sergey Gushcha², Olena Gozhenkol, \\ Valentina Vasyuk, Yana Kutsenko ${ }^{4}$, Radosław Muszkieta ${ }^{5}$, Walery Zukow
}

${ }^{1}$ State Enterprise Ukrainian Research Institute for Medicine of Transport, Ministry of Health of Ukraine, Odesa, Ukraine

${ }^{2}$ State Institution Ukrainian Research Institute of Medical Rehabilitation Land Resort Therapy, Ministry of Health of Ukraine, Odesa, Ukraine

${ }^{3}$ HSEE of Ukraine "Bukovinian State Medical University", Chernivcy, Ukraine

${ }^{4}$ Kyiv National University, Kyiv, Ukraine

${ }^{5}$ Nicolaus Copernicus University, Torun, Poland

\begin{abstract}
Background. Metabolic Syndrome (MS) is a widespread pathological condition, a group of interconnected metabolic disorders that contribute to the development of a number of severe noncommunicable diseases. Natural mineral waters of various compositions are widely used in the correction of MS. Their biological activity and specificity of action is associated with the presence of specific components (micronutrients, biologically active substances). At the same time, many researchers do not pay enough attention to the role of the biological activity of macro nutrients in low mineralized mineral waters.

Objective. To assess the corrective effect of macro-components of mineral waters based on a comparative analysis of changes in the structure of internal organs of white rats with the MS model, receiving mineral waters of the same balneological type, but with different quantitative composition of macro components.

Materials and methods. The material for histological and histochemical tests were the internal organs of male white rats with body weight 280-320 g. Animals were ranked into 4 groups: I - rats served as a control, II - rats with a model of MS; III and IV - rats received the mineral waters against the background of MS modeling. The mineral waters used in the work were characterized by an increased (in close amounts) content of organic substances (C org.), similar in chemical but different in quantitative macro-component composition. At the same time, mineral waters practically did not differ in terms of total mineralization. Modeling of MS was carried out for 60 days by replacing $10 \%$ fructose solution in drinking water bowls, introducing white bread crackers into the diet, and excluding green mass from the diet. In groups where animals were corrected for MS, mineral waters were administered with an intragastric tube with olive at a dose of $1 \%$ of body weight daily, starting from the 60th day of the experiment, for 12 days. Upon completion of the experiment on day 72, histological sections (which were stained with hematoxylin-eosin) were prepared from the extracted pieces of the heart, stomach, liver and kidneys tissues. The succinate-dehydrogenase (SDH) and lactate-dehydrogenase (LDH) activity were determined on the prepared cryostat sections.

Using a light microscope, changes in the structure of the above organs and changes in the activity of oxidative-restorative enzymes were evaluated.

Results. The activity of oxidative-restorative enzymes was approaching normal; some manifestations of changes in water metabolism in the animal organism persisted. At the end of the use of both mineral waters, a significant decrease was found in the content of visceral fat around the intestines, renal capsule, under the pericardium, which correlated with a decrease in the animal's body weight and restoration of the fasting blood glucose level to the cereal level. The authors believe that the established features of the corrective effect of both mineral waters on changes in the structure of internal organs are explained not so much by the difference in the content and ratio of the bioactive component (C org.), but by differences in the content of macronutrients. In mineral waters obtained by rats of group III, the content of $\mathrm{Cl}-$ and $\mathrm{SO} 4+2$ ions is 2.30 and 3.67 times, and $\mathrm{Ca} 2+$ and $\mathrm{Mg} 2+$ ions are 2.75 and 4.57 more than in mineral waters, which received rats of group IV. However, the content of $\mathrm{HCO}_{-}-, \mathrm{Na}+, \mathrm{K}+$ is 1.14 and 1.30 times higher in the mineral waters obtained by rats of group IV.
\end{abstract}

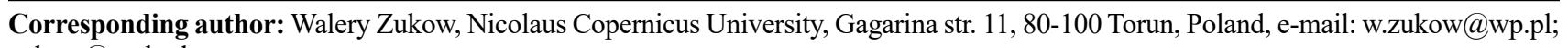
zukow@umk.pl

(C) Copyright by the National Institute of Public Health - National Institute of Hygiene 
Conclusions. The authors believe that the macronutrients involved in the implementation of MWs biological activity affect the metabolic background of the organism, which creates the bioactive element - $\mathrm{C}$ org. conditions for the performance of more intensive corrective action.

Key words: metabolic syndrome, macronutrients, low-mineralized mineral waters

\section{INTRODUCTION}

Metabolic syndrome (MS) - a common pathological condition, which is a group of interconnected metabolic disorders; high blood pressure, an increase in fasting levels of triglycerides and a decrease in fasting levels of high density lipoproteins; increased glucose obesity (excess primarily visceral fat), the development of insulin resistance $[1,3,7,31]$. These metabolic features contribute to the development of non-alcoholic fatty liver disease, type 2 diabetes mellitus, atherosclerosis, arterial hypertension, and cancer pathology [23, 26]. According to the International Diabetes Federation, MS occurs in $20-25 \%$ of the world's population. Moreover, among people aged 18 to 30 years, MS suffers up to $7 \%$ of their total number [22].

In the pathogenesis of MS, today, along with malnutrition, an essential role is given to the metabolism of minerals [15, 32]. Moreover, as indicated in the available literature, mineral waters (MW), due to the high bioavailability of the minerals contained in them, can effectively correct metabolic disturbances characteristic of MS [2, 19, 25]. Among the many ions contained in mineral waters, significant for the correction of MS, along with $\mathrm{Ca}^{+2}, \mathrm{Mg}^{+2}$ consider ions $\mathrm{HCO}_{3}^{-}, \mathrm{Cl}^{-}, \mathrm{Na}^{+}[6$, $8,11]$. It should be noted that in accessible publications the emphasis is on the influence of the above ions on metabolic parameters. At the same time, the state of metabolism is closely related to the state of the substrate of metabolic processes, that is, with the structural and functional characteristics of internal organs.

Since in the available literature we did not meet data on the effect of mineral waters of various compositions on the structural and functional state of internal organs during the development of MS, the goal of our work was formulated as follows.

On the basis of a comparative analysis of changes in the structure of internal organs of white rats with a model of the metabolic syndrome treated with mineral waters, to evaluate the corrective effect of macro-ions contained in these waters on these changes.

\section{MATERIALS AND METHODS}

The material of this study was the data obtained during the study of white male Wistar rats of outbred breeding weight $240-270$ g. Certified animals were obtained from the kennel of the emergency „Biomodelservice” GI „Pharmacology and toxicologists of NAMSof Ukraine", Kyiv.
The work with the animal was carried out in accordance with the requirements of the European Parliament Directive [9] and the Order of the Ministry of Education and Science, Youth and Sports of Ukraine [20].

In accordance with the objectives of the work, animals were ranked in 4 groups.

I group - 15 intact rats, kept under vivarium conditions, but were not exposed to any treatment and served as a control. II group - 10 rats in which metabolic syndrome (MS) was simulated for 60 days. III group 10 rats, which, against the background of MS modeling, received mineral water of sample No. 1. IV group - 10 rats, which against the background of the simulation of MS received mineral water of sample No. 2.

Modeling of a metabolic syndrome was carried out for 60 days by replacing drinking water with a $10 \%$ solution of fructose and introducing white bread crackers into the standard diet. In groups where animals were corrected for MS, mineral waters were injected with an intragastric tube with olive at a dose of $1 \%$ of body weight daily, starting from the 60th day of the experiment, for 12 days. Weighed animals weekly. At the end of the experiment on day 72, the animals were removed from the experiment by decapitation under ether anesthesia. At an autopsy, after a visual assessment of internal organs, pieces of the heart, stomach, liver, and kidneys were taken in a volume of $1 \mathrm{~cm}^{3}$. A piece of organ was divided into two parts. One part was fixed in $4 \%$ steam with formaldehyde for 48 hours, then it was passed through alcohols of increasing concentration and poured into celloidin according to the generally accepted method. Sections 7-9 $\mu \mathrm{m}$ thick were made from the obtained blocks, which were stained with hematoxylin-eosin. The resulting preparations were examined under a light microscope to determine structural changes in the internal organs. The second part of the piece was frozen with dry carbon dioxide $\left(\mathrm{t}=-44^{\circ} \mathrm{C}\right)$. Cryostat sections $11 \mu \mathrm{m}$ thick were made from the obtained blocks, on which the activity of succinatedehydrogenase $(\mathrm{SDH})$ and lactate-dehydrogenase (LDH) were determined according to the Lloyd $\mathrm{K}$. prescriptions; enzyme activity was evaluated by the semi-quantitative method, the data were given in arbitrary units of optical density (conventional units) $[17,21]$. The concentration of glucose in the blood was determined on an empty stomach using the glucose oxidant method [12]. Statistical processing of the obtained data was carried out using the biomedical 
research programms Statistica and Exel. Significant changes were considered those that were within the confidence limits according to Student tables $<0.05$.

In the work we used mineral waters of two samples with a high content of organic substances (C org.), low mineralization, the physicochemical characteristics of which are shown in Table 1. A sample of mineral water No. 1 was taken from well No. 77 of the Romanovka village, Chemerovetsky district, Khmelnitsky region (Ukraine). Mineral water sample No. 2 was taken from well No. 357 Skhidnytsyavillage, Drohobych district, Lviv region (Ukraine). The content of organic carbon in both waters is balneologically significant, which, with a total mineralization of up to $1 \mathrm{~g} / \mathrm{dm} 3$, determines their name and classifies them as lowmineralized waters with a high content of organic substances (better known as mineral waters of the Naftusya type) [27]. In mineral water No. 1, it is more (by $20 \%$ ). Moreover, the content of biologically active components such as $\mathrm{H}_{2} \mathrm{~S}$ and $\mathrm{H}_{2} \mathrm{SiO}_{3}$ is significantly higher in mineral waters No. 2, however, their concentration is lower than balneological significant. The content of other biologically active components and compounds in both waters is also below the balneological norm [30]. In general, we can assume that in terms of their physicochemical composition and biological activity these waters are fairly close.

\section{RESULTS AND DISCUSSION}

Before proceeding to the presentation of the research results, we considered it necessary to conduct a comparative analysis of the mineral waters used in the work. According to the data in Table 1, the total mineral content in both waters is almost the same $835.00 \mathrm{mg} / \mathrm{dm}^{3}$ in mineral water of sample No. 1 and $827.00 \mathrm{mg} / \mathrm{dm}^{3}$ in mineral water of sample No 2. However, the content of individual ions varies. In mineral waters No. 1, in comparison with mineral waters No. 2, the content of chlorine ions $\left(\mathrm{Cl}^{-}\right)$and $\mathrm{SO}_{4}^{+2}$ sulfates are 2.30 and 3.67 times higher, while the content of calcium $\left(\mathrm{Ca}^{2+}\right)$ ions of magnesium $\left(\mathrm{Mg}^{2+}\right)$ is 2.75 and at 4.57 . At the same time, the content of bicarbonates $\left(\mathrm{HCO}_{3}^{-}\right)$, sodium and potassium $\left(\mathrm{Na}^{+}+\right.$ $\mathrm{K}^{+}$) is 1.14 and 1.30 times higher in mineral water No 2 .

In animals of group II (model MS without correction) it was found that within two months they gained more weight than animals of group I of the control group. If the initial weight of animals of this group was (305.0 \pm $0.85) \mathrm{g}$, and animals of group II - $(283.1 \pm 0.21) \mathrm{g}$, then on the 60th day of the experiment the body weight of animals of group I was - $(325.3 \pm 1.04) \mathrm{g}$, and group II $(323.5 \pm 0.44) \mathrm{g}$ (Figure 1). The increase in body weight of animals with the MS model was 2 times greater in comparison with animals of group I. This is not a large increase in body weight, as fructose diet does not lead to a large weight gain, as noted by other authors, but the data are contradictory [5, 28, 29]. A more pronounced weight gain provides a variety of diets with fructose, glucose or sucrose, and high fat (fast food diet, or cafe diet) $[11,18]$. In rats of the III and IV groups, weight gain on the 60th day of the experiment was similar to that of the group with MS. In rats of group III, it increased from $(293.6 \pm 1.13) \mathrm{g}$ to $(343.2 \pm 1.02) \mathrm{g}$, and in animals of group IV, body weight increased from $(299.8 \pm 1.15) \mathrm{g}$ to $(349.5 \pm 0.87) \mathrm{g}$.

At the same time, the glucose concentration in the blood of animals of the II, III and IV groups on the

Table 1. Macro elemental, micro elemental composition and biologically active components, and mineral waters compounds, $\mathrm{mg} / \mathrm{dm}^{3}$

\begin{tabular}{|c|c|c|c|c|c|c|}
\hline \multirow[b]{2}{*}{ Indicators } & \multicolumn{2}{|c|}{$\begin{array}{l}\text { Macro elemental } \\
\text { composition }\end{array}$} & \multirow[b]{2}{*}{ Indicators } & \multicolumn{3}{|c|}{$\begin{array}{l}\text { Micro elemental } \\
\text { composition }\end{array}$} \\
\hline & $\begin{array}{c}\text { Mineral water } \\
\text { sample } \\
\text { number } 1\end{array}$ & $\begin{array}{c}\text { Mineral water } \\
\text { sample } \\
\text { number } 2\end{array}$ & & $\begin{array}{l}\text { Mineral water } \\
\text { sample } \\
\text { number } 1\end{array}$ & $\begin{array}{c}\text { Mineral water } \\
\text { sample } \\
\text { number } 2\end{array}$ & $\begin{array}{l}\text { Balneological } \\
\text { significant } \\
\text { concentration } \\
\text { no less }\end{array}$ \\
\hline $\begin{array}{l}\text { Overall } \\
\text { mineralization }\end{array}$ & 835.00 & 827.00 & $\begin{array}{l}\text { Organic materials } \\
\text { (carbon org.) }\end{array}$ & 14.00 & 11.40 & $5.0-30.0$ \\
\hline $\begin{array}{l}\text { Bicarbonates } \\
\left(\mathrm{HCO}_{3}^{-}\right)\end{array}$ & 476.70 & 542.90 & $\begin{array}{l}\text { Hydrogen sulfide, } \\
\left(\mathrm{H}_{2} \mathrm{~S}\right)\end{array}$ & 0.36 & 2.54 & 10.0 \\
\hline Chlorides $\left(\mathrm{Cl}^{-}\right)$ & 56.73 & 24.80 & $\begin{array}{l}\text { Orthoboric acid } \\
\qquad\left(\mathrm{H}_{3} \mathrm{BO}_{3}\right)\end{array}$ & 13.98 & 15.45 & 35.0 \\
\hline Sulfates $\left(\mathrm{SO}_{4}^{2-}\right)$ & 33.00 & 9.00 & $\begin{array}{l}\text { Metasilicic acid, } \\
\left(\mathrm{H}_{2} \mathrm{SiO}_{3}\right)\end{array}$ & 16.46 & 26.86 & 50.0 \\
\hline $\begin{array}{l}\text { Sodium \& potassium } \\
\left(\mathrm{Na}+, \mathrm{K}^{+}\right)\end{array}$ & 163.62 & 213.60 & Bromine, $(\mathrm{Br})$ & 0.08 & 0.08 & 25.0 \\
\hline Calcium $\left(\mathrm{Ca}^{2+}\right)$ & 33.00 & 12.00 & Total iron, $(\mathrm{Fe})$ & 0.20 & 0.50 & 10.0 \\
\hline Magnesium $\left(\mathrm{Mg}^{2+}\right)$ & 27.80 & 6.10 & Iodo, (I) & 0.127 & 0.127 & $0.7-1.5$ \\
\hline
\end{tabular}




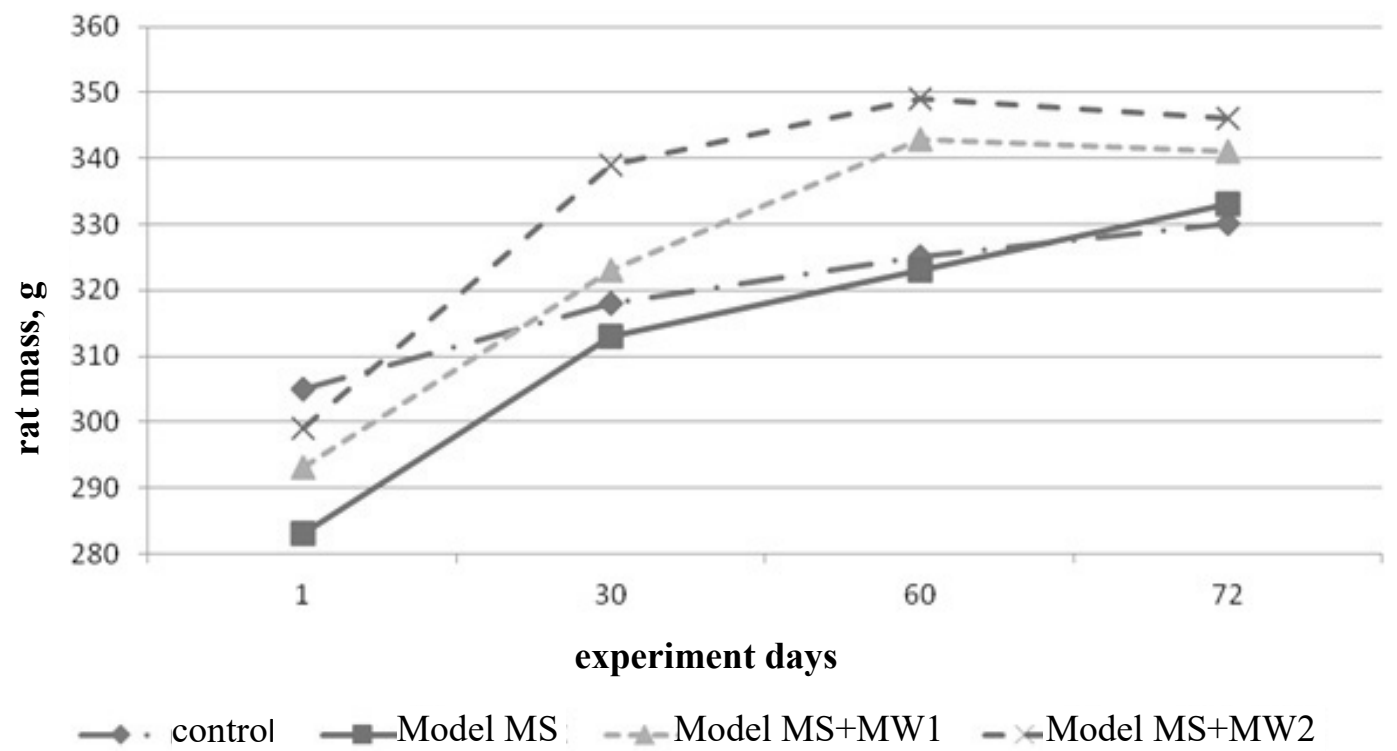

Figure 1. Dynamics of rat mass model MS and rats with MS in correction of mineral waters (MW1 and MW2) with increased organic content and various quantitative macro composition

60th day of the experiment was $(8.06 \pm 0.33) \mathrm{mmol} / \mathrm{L}$, which was 2.95 per $\mathrm{mmol} / \mathrm{L}$ higher than the data of the 1st control group (Figure 2). The data we have obtained on elevated glucose levels are cited by other researchers $[4,14]$.

Autopsy of animals of group II at the end of the experiment revealed that the main increase in adipose tissue was due to visceral fat in the renal capsule and its surrounding space so much that renal excretion becomes difficult; a lot of fat on the surface of the intestine, quite a lot under the pericardium. The liver did not visually change its size and shape, although its tissue acquired a yellow-brown color.
In microscopic examination of the wall of the stomach showed swelling of the submucosal plate, the nuclei of the fibroblasts are dark, elongated, small, their number is moderate. In the mucous membrane, the broadening of interstitial layers and their turbidity attracted attention.

Glands of the gastric mucosa of a tubular shape, their location due to varying degrees of expansion of the interstitial layers is disordered. The epithelium in some glands is desquamated. In the epithelial cells, the nuclei are small dark, in the cytoplasm of many cells, small vacuoles. SDH activity in epithelial cells

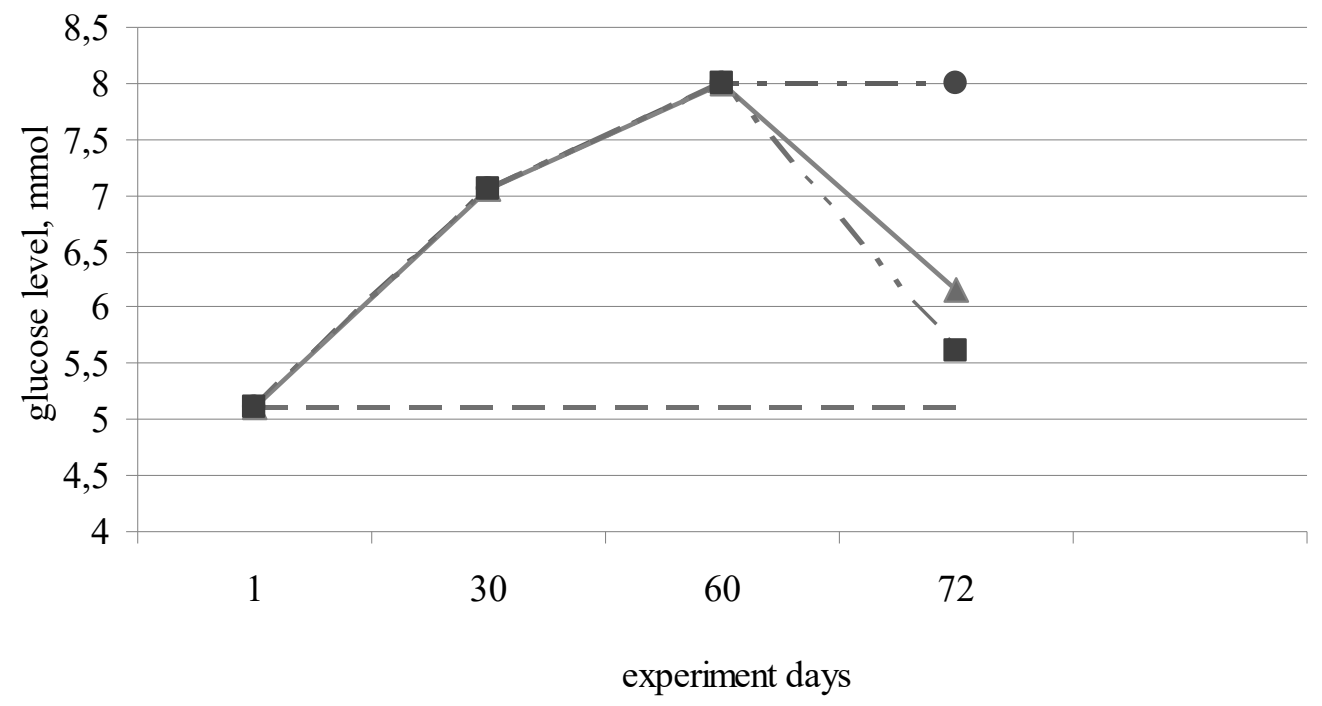

-- control $-\bullet-$ Model MS $\longrightarrow$ Model MS+MW1 $-\square$ - Model MS+MW2

Figure 2. Dynamics of glucose levels in rats with MS and rats with MS during correction of mineral waters (MW1 and MW2) with an increased content of organic substances and various coliseum macro composition 
$(7.0 \pm 0.21)$ conv. units; LDH activity - $(7.00 \pm 0.12)$ conv. units (increased).

In microscopic examination of the liver it is established that the dolce organization of the parenchyma of the liver is preserved. Between the wedge layers are thin, dense vessels of the triad and the central vein of moderate blood filling. Hepatocytes in slices are small, collected in beams. The nuclei of hepatocytes are small, dark-colored, cytoplasm weakly basophil lumpy organization, contain small and medium vacuoles. Between beam spaces are slit, Kupffer's cells are swollen (the nuclei are rounded). Small eosinophil inclusions are defined in parenchyma. The activity of SDH in hepatocytes is - (7.0 to 0.31$)$ Ed.; LHG's activity is (6.0 to 0.13 ) units.

In myocardium, in microscopic examination of the myocardium indicates the preservation of the layered and bundle organization, interbeam interlayers are broadened due to their swelling. Cardiomyocytes are characterized by fuzzy transverse streakiness and an oval shape of enlarged nuclei (swelling). SDH activity in cardiomyocytes $(7.0 \pm 0.19)$ conv. units; LDH activity - $(6.0 \pm 0.25)$ conv. units.

In the kidneys, the distribution of renal bodies is uneven. In capillary glomeruli, endotheliocytes are swollen; small vacuoles are determined in their cytoplasm. Bowman's space is slit-like, apparently due to swelling of the capillary glomerulus. The interstitial layers are expanded due to the presence of lymphocytes in them. In part of the convoluted tubules in the lumen, eosinophilic homogeneous cylinders are determined. The tubule epithelium with swelling of the cytoplasm and small dark nuclei. In some tubules, the lumen is expanded to the state of lacunae. The activity of SDH in the tubular epithelium $6.0 \pm 0.30$ conv. units; LDH activity in them $6.0 \pm 0.11$ conv. units. In our previous work it is shown that rats on the background of MS develop pathological disorders of urinary and excretory functions of the kidneys, which led to a violation of the water-ion balance in the body [13].

In general, we observed the presence of signs of dystrophy in the studied internal organs of animals with a model of MS. The evidence we have established is confirmed by other researchers, who cite evidence that during fructose metabolism there is an arthosis depletion, which causes oxidative stress and inflammatory response, disrupting the functions of local tissues and organs, causing overproduction of inflammatory cytokines, adiponectin, leptin and endotoxin, which act as indirect dangerous factors. Fructose and its metabolites both directly and indirectly cause oxidative stress, chronic inflammation, endothelial dysfunction of autophagy and increased intestinal permeability, which further aggravates the course of metabolic syndrome with subsequent dysfunction of organs and tissues, namely liver, fatty tissue, islets of the pancreas, skeletal muscles, kidneys, heart, brain and bowel[16, 33].

By the end of the experiment (72nd day), the animals of the control group added another $5 \mathrm{~g}$ in weight, which amounted to $(330.3 \pm 0.09) \mathrm{g}$ of body weight, animals of the II group with the MS model added $10 \mathrm{~g}$ in weight $(333.5 \pm 0.07) \mathrm{g}$ (Figure 1$)$. The use of mineral water as a corrective agent, according to our observations, influenced body weight gain. If in the control group for the entire duration of the experiment the animals gained $(30.0 \pm 0.14) \mathrm{g}$, in the group with uncorrected MS, the weight gain was (50.7 $\pm 0.19) \mathrm{g}$, then in the groups where animals with the MS model received the corresponding mineral water, the weight gain was less, and was - $(28.0 \pm 0.42) \mathrm{g}$ in the III group and $-(30.2 \pm 0.18) \mathrm{g}$ in animals of the IV group receiving mineral water No. 2 .

This was manifested primarily in a smaller amount of visceral fat and was accompanied by positive changes in the structural characteristics of the internal organs of animals. It should be noted that there were some features of these changes in animals treated with mineral water No. 1 (MW1) and mineral water No 2 . (MW2).

Microscopic examination of the stomach wall of animals of the experimental group showed that the submucosal plate is dense, it is not possible to visually separate individual bundles of fibrous fibers. It determines a moderate amount of dark elongated fibroblast nuclei. In the mucous membrane of the gland of the usual tubular form. The interstitial layers are not wide. In the deep layers of the mucosa, the glands in their appearance correspond to the descriptions of the literature. The glands of the surface layers are characterized by light-colored cytoplasm, a homogeneous structure, in some small vacuoles are determined. Nuclei in medium sized epithelial cells of moderate color. The activity of SDH in the epithelial cells of the glands of the deep layers of the mucosa is ( $7.0 \pm 0.21)$ conv. units; activity of SDH in the surface layers $-(5.0 \pm 0.11)$ conv. units LDH activity in the epithelial cells of the deep layers $-6.0 \pm 0.19$ conv. units, in the surface - $(5.0 \pm 0.20)$ conv. units.

Microscopic examination of the liver showed lobular organization of the parenchyma. Between the lobular layers are thin, dense. Vessels of triads of moderate blood filling. Hepatocytes in lobules are collected in beams, most of them are medium-sized. Regarding the lobules, the hepatocytes are of the usual type, their cytoplasm is homogeneous, the nuclei are of medium size, moderate in color. In part of the lobules, along with the usual type of hepatocytes, cells with a lumpy cytoplasm, in which there are single small vacuoles, are determined. The inter-beam spaces are slit-like, the nuclei of Kupffer cells are flattened, dark. In segments with the usual type of hepatocytes, the 
activity of SDH is - $(6.0 \pm 0.13)$ conv. units; in segments of hepatocytes with vacuoles - $(5.0 \pm 0.13)$ conv. units; $\mathrm{LDH}$ activity is uniform in all segments and is $-(6.0 \pm$ $0.30)$ conv. units.

When examining the myocardium, violations of its layered and bundle organization were not detected. Interbeam interlayers are thin, dense, vessels of moderate blood filling. Cardiomyocytes of the usual form. SDH activity - $(7.0 \pm 0.16)$ conv. units; LDH activity in cardiomyocytes is slightly increased, and is $-(7.0 \pm 0.21)$ conv. units.

In the study of the kidneys, it was determined that the renal corpuscles are distributed fairly evenly. In most of them, capillary glomeruli are rounded in shape, with endothelial cells of the usual form. In individual renal bodies, the swelling of the endothelial cells of the glomeruli of capillaries and the presence of small vacuoles in them are determined. The tubules of the kidneys are of normal appearance, their gaps are free. The activity of SDH in the epithelium of the tubules is - (7.0 \pm 0.19$)$ conv. units; LDH activity - (5.0 $\pm 0.30)$ conv. units.

In general, we observed the positive effect of drinking mineral water of sample No. 1 on the structural characteristics of the internal organs of animals with the MS model (group 3 rats).

Assessing the structural and functional characteristics of the internal organs of rats with a model of MS treated with mineral water No. 2 (group 4 animals), a number of positive changes can be noted. Under microscopy of the stomach, the submucosal plate is dense, the fibrous fibers are packed without breaks, it is impossible to visually separate individual bundles or fibers. In the mucous membrane of the gland of the usual tubular form, the epithelium lines them in one layer. Epithelial cells with a homogeneous weakly basophilic cytoplasm, medium sized nuclei are juicily stained. The interstitial layers remain broadened, as in animals with an uncorrected metabolic syndrome. The activity of SDH in epithelial cells is $(7.0 \pm 0.19)$ conv. units, $\mathrm{LDH}$ activity in them - $(6.0 \pm 0.27)$ conv. units.

In the liver, microscopic examination determines the lobular organization of the parenchyma. The interlobular layers are thin dense. The vessels of the triads, the central vein are sharply full-blooded. Hepatocytes are collected in beams on most of the lobules. Medium sized hepatocytes, their lumpy cytoplasm, nuclei of medium and small sizes, juicyly painted over. The cytoplasm of the hepatocytes contains small vacuoles, swollen. In lobules, single small homogeneous structures of eosinophilic inclusions are determined. Between the beam spaces are slit-like. Kupffer cell nuclei are flattened, darkly stained. The activity of SDH in hepatocytes compared with that of the control group is reduced, and is $(5.0 \pm 0.17)$ conv. units; LDH activity is - $(6.0 \pm 0.10)$ conv. units.
Myocardial examination showed that its layer and bundle organization is not changed. Interbeam interlayers are thin and dense. In cardiomyocytes, the cytoplasm with pronounced transverse striation, the nuclei are small, darkly colored, oval in shape. The activity of SDH in cardiomyocytes is $(7.0 \pm 0.35)$ conv. units; LDH activity - $(6.0 \pm 0.34)$ conv. units, i.e., the activity of oxidative-restorative enzymes corresponds to the norm.

Microscopic examination of the kidneys revealed the uneven distribution of renal bodies. In the renal corpuscles, capillary glomeruli are rounded, endotheliocytes in the capillaries are swollen, in some of them small vacuoles are observed, the nuclei of the endotheliocytes are small, darkly colored. Most tubules are of a normal form, however, tubules with swollen, unclear cytoplasm are found in the lumen of which desquamated epithelial cells are determined. The interstitial layers are mostly thin, but broadened layers with swollen fibrous fibers are also found. The activity of SDH in the tubule epithelial cells is (7.0 \pm $0.19)$ conv. units; LDH activity in them is reduced to (5.0 \pm 0.10$)$ conv. units.

In general, we can talk about the approximation of the structure of internal organs to normal. Only in the liver and kidneys are manifestations of dystrophic processes preserved.

A feature of correcting mineral water No. 1 was its uneven expression in different parts of the same organ (group 3 of rats), which distinguished the effect of this mineral water from the effect of mineral water No. 2 (group 4 animals). It should be emphasized that in rats of groups 3 and 4, at the end of the use of both mineral waters, a significant decrease in the content of visceral fat in the renal capsule, under the pericardium and around the intestines was detected, which correlated with a decrease in animal body weight and restoration of fasting blood glucose levels (Figure 2). At the end of the experiment, in rats of the III group, the glucose concentration was $(6.16 \pm 0.13) \mathrm{mmol} / \mathrm{L}$, and in rats of the IV group - $(5.62 \pm 0.19) \mathrm{mmol} / \mathrm{L}$, which did not significantly differ from the control group.

Mineral waters containing organic substances, as the main bioactive agent, have a positive effect on the structural characteristics of the internal organs of rats with the MS model. It was manifested in a decrease or absence of signs of dystrophic processes. It should be noted that there were differences in the prevalence of these positive changes. In both cases, after the application of these mineral waters in the myocardium, no manifestations of dystrophy were detected. In the stomach wall, residual manifestations of dystrophy when applying mineral water No. 1 were noted in the glands of the surface layers of the gastric mucosa, and when using mineral water No. 1, they were not detected. In the liver parenchyma, residual 
manifestations of dystrophic processes were noted in the cases of using both mineral waters, however, in the case of using mineral water No. 1 , they are determined in the parenchyma of part of the lobules, and in the case of using mineral water No. 2 in all segments.

Accordingly, in the kidneys in both cases, the use of mineral water in the capillaries of the glomeruli of the renal corpuscles retains residual manifestations of dystrophic changes, but in the tubules when using mineral water No. 2, they are more common. In our opinion, it is incorrect to associate the revealed differences with different amounts of the bioactive component, since according to the data in Table 2, the difference does not exceed $2.45 \mathrm{mg} / \mathrm{dm}^{3}(20 \%)$. At the same time, the difference in the content of the components of the macronutrient component used mineral water is very significant. In mineral water No. 1, in comparison with mineral water No. $2, \mathrm{SO}_{4}{ }^{+2}$ and $\mathrm{Cl}^{-}$ions are 3.67 and 2.30 times more, and $\mathrm{Ca}^{2+}$ and $\mathrm{Mg}^{2+}$ ions are 2.75 and 4.55 times more, respectively. At the same time, mineral water No. 357 contains more $\mathrm{HCO}_{3}^{-}, \mathrm{Na}^{+}+\mathrm{K}^{+}$ions and biologically active components in the form of $\mathrm{H}_{2} \mathrm{~S}$, and $\mathrm{H}_{2} \mathrm{SiO}_{3}$.

Since $\mathrm{SO}_{4}^{+2}$ ions affect the metabolic processes in hepatocytes, it can be assumed that their higher content in mineral water No. 1 determines the features of structural changes in the liver; the higher $\mathrm{Cl}^{-}$ content in the same mineral water obviously causes a difference in the structural structure of the renal tubules. Differences in the content of $\mathrm{Ca}^{2+}$ and $\mathrm{Mg}^{2+}$, $\mathrm{H}_{2} \mathrm{~S}$, and $\mathrm{H}_{2} \mathrm{SiO}_{3}$ ions - affecting the course of metabolic processes and hemodynamic characteristics, obviously also affect the revealed differences in the structural changes in the internal organs of experimental rats.

The data we have obtained on the corrective effect of MW on the body of rats with the MS model largely coincide with the few on this problem data of studies conducted studies on rats with fructose MS. The authors point to the significant positive effect of the use of MW on the metabolic rates studied in the development of MS [24].

\section{CONCLUSIONS}

Thus, the research results show that when assessing the biological activity of low-mineralization MW (up to $1 \mathrm{~g} / \mathrm{dm}^{3}$ ) it is necessary to take into account that the macronutrient composition of $\mathrm{MW}$, influencing the metabolic background of the body, creates conditions for enhancing the curative effect of a specific bioactive element ( $\mathrm{C}$ org.). Therefore, the amount and ratio of macroelements should be taken into account when assessing this type of mineral waters biological activity.

\section{Conflict of interest}

The authors declare no conflict of interest.

\section{REFERENCES}

1. Alberti KG, Eckel RH, Grundy SM, et al.: Harmonizing the metabolic syndrome: A joint interim statement of the International Diabetes Federation Task Force on Epidemiology and Prevention; National Heart, Lung, and Blood Institute; American Heart Association; World Heart Federation; International Atherosclerosis Society; and International Association for the Study of Obesity. Circulation. 2009;120:1640-1645. doi: 10.1161/ CIRCULATIONAHA.109.192644.

2. Albertini MC, Dacha M, Teodori L, Conti ME.: Drinking mineral waters: biochemical effects and health implications - the state of the art. Int. J. Environmental Health. 2007;1(1):153-169. doi: https://doi.org/10.1504/ IJENVH.2007.012230.

3. Alcala-Diaz JF, Delgado-Lista J, Perez-Martinez P, et al.: Hypertriglyceridemia influences the degree of postprandial lipemic response in patients with metabolic syndrome and coronary artery disease: From the CORDIOPREV study. PLoS ONE.2014, 9, e96297. doi: 10.1371/journal.pone.0096297.

4. Ajiboye TO, Aliyu H, Tanimu MA, Muhammad RM, Ibitoye OB.: Dioscoreophyllum cumminsii (Stapf) Diels leaves halt high-fructose induced metabolic syndrome: Hyperglycemia, insulin resistance, inflammation and oxidative stress. J Ethnopharmacol. 2016. Nov 4;192:471-479. doi: 10.1016/j.jep.2016.08.024.

5. Bi XP, Tan HW, Xing SS, et al.: Overexpression of TRB3 gene in adipose tissue of rats with high fructoseinduced metabolic syndrome. Endocr. J. 2008;55:747752. doi: 10.1507/endocrj.K08E-049.

6. Chalaya EN, Botvineva LA, Tsallagova LV, et al.: The SPA and health resort-based treatment of metabolic syndrome with the application of the therapeutic courses of different duration: the evaluation according long-term results. Vopr Kurortol Fizioter Lech Fiz Kult. 2017;94(3):27-31. doi: 10.17116/kurort201794327-31.

7. Costa-Vieira D, Monteiro R, Martins MJ.: Metabolic Syndrome Features: Is There a Modulation Role by Mineral Water Consumption? A Review. Nutrients 2019;11(5): pii: E1141. doi: 10.3390/nu11051141.

8. De Giglio $O$, Quaranta A, Lovero $G$, Caggiano $G$, Montagna MT:: Mineral water or tap water? An endless debate. Ann. Ig. 2015;27(1):58-65. doi: 10.7416/ ai.2015.2023.

9. Directive $2010 / 63 /$ EU of the European Parliament and of the Council of 22 September 2010 on the protection of animals used for scientific purposes. Official Journal. 2010;276:0033-0079. https://eur-lex.europa.eu/ LexUriServ/LexUriServ.do?uri=OJ:L:2010:276:0033:00 79:EN:PDF

10.Dobrian AD, Davies MJ, Prewitt RL, Lauterio TJ.: Development of hypertension in a rat model of dietinduced obesity. Hypertension. 2000;35:1009-15. doi: 10.1161/01.HYP.35.4.1009.

11. European Council. Directive 2009/54/EC of the European Parliament and of the Council of 18 June 2009 on the Exploitation and Marketing of Natural Mineral Waters; European Council: Brussels, Belgium, 2009. 
12.Gorjachkovskij A.M.: Klinicheskaja biohimija v laboratornoj diagnostike / A.M. Gorjachkovskij. izd. 3-e. Odessa: Jekologija, 2005;608.

13. GushchaSG, NasibullinBA, ZukowW, VolyanskaVS.:Influence of mineral water on the structural and functional state of the rat's kidneys with metabolic syndrome. Journal of Education, Health and Sport. 2019;9(1):11-21. doi: http://dx.doi.org/10.5281/ zenodo.3466125.

14. Huang BW, Chiang MT, Yao HT, Chiang W.: The effect of high-fat and high-fructose diets on glucose tolerance and plasma lipid and leptin levels in rats. Diabetes Obes. Metab. 2004;6:120-126. doi: 10.1111/j.14628902.2004.00323.x.

15. Kern HJ, Mitmesser SH.: Role of nutrients in metabolic syndrome: a 2017 update. Nutrition and Dietary Supplements. 2018:10 13-26. doi: 10.2147/NDS. S148987.

16.LehnenAM, RodriguesB, IrigoyenMC, De AngelisK, SchaanBD'A.:Cardiovascular Changes in Animal Models of Metabolic Syndrome. J Diabetes Res. 2013; 2013: 761314. doi: 10.1155/2013/761314.

17. Lojda Z, Grossrau R, Schiebler TN.: Enzyme Histochemistry. A Laboratory Manual. Springer-Verlag Berlin-Heidelberg New York 1979.

18. Moreno-FernándezS, Garcés-RimónM, VeraG, AstierJ, LandrierJF, MiguelM.:High Fat/High Glucose Diet Induces Metabolic Syndrome in an Experimental Rat Model.Nutrients. 2018 Oct;10(10):1502. doi: 10.3390/ nu10101502.

19. Nakamura, E.; Tai, H.; Uozumi, Y.; Nakagawa, K.; Matsui, T: Magnesium absorption from mineral water decreases with increasing quantities of magnesium per serving in rats. Nutr. Res. 2012;32:59-65. doi: 10.1016/j. nutres.2011.11.001.

20. Nakaz Ministerstva osviti i nauki, molodi ta sportu Ukraïni vid 01.03.2012 № 249 «Pro zatverdzhennja Porjadku provedennja naukovimi ustanovami doslidiv, eksperimentiv na tvarinah». [in Ukrainian]. Order of Ministry of Education and Science, Youth and Sport of Ukraine No. 249 dated 01.03.2012. Official Journal of Ukraine dated 06.04.2012, article 942, № 24, 82 p., code of the act 60909/2012. (in Ukrainian).URL: https:// zakon.rada.gov.ua/laws/show/z0416-12/print.

21. Nakaz MOZ Ukraïni vid 28.09.2009 r. № 692 «Pro zatverdzhennja metodichnih rekomendacij $\mathrm{z}$ metodiv doslidzhen' biologichnoï diï prirodnih likuval'nih resursiv ta preformovanih likuval'nih zasobiv». Order of MOH of Ukraine No. 692 dated 28.09.2009 «On approval of the recommendations of the research methods of biological effects of natural medicinal resources and preformed remedies». URL: http://old. moz.gov.ua/ua/portal/dn_20090928_692.html.

22.Nolan PB, Carrick-Ranson G, Stinear JW, Reading $S A$, Dalleck LC.: Prevalence of metabolic syndrome and metabolic syndrome components in young adults: A pooled analysis. Prev. Med. Rep. 2017;7:211-215. doi: 10.1016/j.pmedr.2017.07.004.
23. Paschos $P$, Paletas $K$. : Nonalcoholic fatty liver disease and metabolic syndrome. Hippokratia. 2009;13(1):9-19. https://www.ncbi.nlm.nih.gov/pmc/ articles/PMC2633261.

24. Pereira CD, Passos E, Severo $M$, et al.: Ingestion of a natural mineral-rich water in an animal model of metabolic syndrome: effects in insulin signalling and endoplasmic reticulum stress. Hormone Molecular Biology and Clinical Investigation. 2016 May;26(2):135150. DOI: $10.1515 / \mathrm{hmbci}-2015-0033$.

25. Petraccia L, Liberati $G$, Masciullo SG, Grassi $M$, Fraioli A.: Water, mineral waters and health. Clin. Nutr. 2006;25:377-385. doi: 10.1016/j.clnu.2005.10.002.

26.Puente D, López-Jiménez T,Cos-Claramunt X,Ortega $Y$,Duarte-Salles T. Metabolic syndrome and risk of cancer: a study protocol of case-control study using data from the Information System for the Development of Research in Primary Care (SIDIAP) in Catalonia. BMJ Open. 2019;9(6):e025365. doi: 10.1136/ bmjopen-2018-025365.

27. Shestopalov VM, Moiseeva NP, Ishchenko AP. et al.Lechebnye mineral'nye vody tipa «Naftusja» Ukrainskih Karpat i Podol'ja. Bukrek, 2013. 600 s. ILI na angl. Naftusia medical waters of Ukrainian Carpathians and Podolia. Chernovtsy: Bukrek, 2013: $600 \mathrm{p}$.

28. Thirunavukkarasu V, Anitha Nandhini AT, Anuradha $C V$.: Lipoic acid attenuates hypertension and improves insulin sensitivity, kallikrein activity and nitrite levels in high fructose-fed rats. J Comp Physiol B.2004;174:58792. doi: 10.1007/s00360-004-0447-z. 24.

29. ToopCR, GentiliS.: Fructose Beverage Consumption Induces a Metabolic Syndrome Phenotype in the Rat: A Systematic Review and Meta-Analysis. Nutrients. 2016 Sep;8(9):577. doi: 10.3390/nu8090577.

30. Vodi mineral'ni fasovani. Tehnichni umovi: DSTU 878-93. [Chinnijvid 1995-01-01]. Kiïv: Derzhstandart Ukraïni, 1994. 88 s. Derzhavnij standart Ukraïni. Mineral waters in packaging. Technical conditions: DSTU 878-93. [Existing from 1995-01-01]. Kyiv: State standard of Ukraine, 1994. 88.

31. Welty FK, Alfaddagh A, Elajami TK.: Targeting inflammation in metabolic syndrome. Transl Res. 2016;167(1):257-80. doi: 10.1016/j.trsl.2015.06.017.

32. World Health Organization. Calcium and Magnesium in Drinking-Water.PublicHealth Significance; WHOPress: Geneva, Switzerland, 2009. URL: https://apps.who.int/ iris/bitstream/handle/10665/43836/9789241563550 eng.pdf;jsessionid=B0FD5CD1C8DEBAD541FE00B13 F3D0CE4? sequence=1.

33.ZhangDM, JiaoRQ, KongLD.:High Dietary Fructose: Direct or Indirect Dangerous Factors Disturbing Tissue and Organ Functions. Nutrients. 2017 Apr; 9(4):335. doi: 10.3390/nu9040335.

Received: 10.05 .2020

Accepted: 02.10.2020

This article is available in Open Access model and licensed under a Creative Commons Attribution-Non Commercial 3.0.Poland License (CC-BY-NC) available at: http://creativecommons.org/licenses/by-nc/3.0/pl/deed.en 